Avoimesti luettavissa osoitteessa http://journal.fi/ainedidaktiikka

ainedidaktiikka

\title{
Yhteiskuntaopin opetus ja poliittinen kiinnittyminen peruskoulun yläluokilla
}

\author{
Miikka Korventausta ${ }^{1}$, Tero Järvinen ${ }^{1}$, Tomi Jaakkola ${ }^{2}$ ja Marjaana Veermans ${ }^{1}$ \\ ${ }^{1}$ Kasvatustieteiden tiedekunta, Turun yliopisto \\ ${ }^{2}$ Kasvatustieteiden ja kulttuurin tiedekunta, Tampereen yliopisto

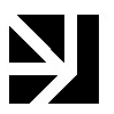 \\ Artikkelissa raportoitavan tutkimuksen kohteena on peruskoulun \\ yhteiskuntaopin opetuksen yhteys nuorten poliittiseen kiinnittymiseen, \\ joka jaetaan tutkimuksessa neljään ulottuvuuteen: poliittiseen kiinnos- \\ tukseen, poliittiseen tietämykseen ja itsearvioon tietämyksestä, poliittiseen \\ osallistumishalukkuuteen sekä politiikkaa koskeviin käsityksiin. Tutkimusaineis- \\ tona on peruskoulun yläkouluikäisten nuorten vastaukset poliittista kiinnittymistä \\ mittaavaan kyselyyn kahtena eri ajankohtana. Osallistujat olivat ensimmäisen \\ mittauksen aikana kahdeksannella luokalla $(n=67)$ ja toisen mittauksen aikana \\ yhdeksännellä luokalla $(n=63)$. Nuoret opiskelivat mittausten välillä lukuvuo- \\ den ajan yhteiskuntaoppia ensimmäistä kertaa koulu-urallaan. Tulosten mukaan \\ nuorten poliittinen kiinnostus, tietämys ja itsearvio tietämyksestä olivat 9. luo- \\ kalla tilastollisesti korkeampia kuin 8. luokalla. Osallistumishalukkuudessa ei \\ havaittu eroja ikäryhmien välillä, ja politiikkaa koskevien käsitysten osalta eroja \\ ilmeni yhden väitteen kohdalla. 8.-luokkalaiset pitivät kotia tärkeimpänä läh- \\ teenä oppia tietoja yhteiskunnallisten asioiden ymmärtämiseksi, kun taas 9.-luok- \\ kalaisille koulu oli keskeisin tietolähde yhteiskunnallisten asioiden oppimisessa. \\ Tulosten mukaan koulu näyttäisi onnistuvan yhteiskunnallisen kasvatuksen \\ tavoitteissaan vain osittain. Jatkossa olisi tärkeää kiinnittää huomiota siihen, \\ miten koulussa voitaisiin tukea tiedollisten sisältöjen oppimisen lisäksi nuorten \\ yhteiskunnallista osallistumista edistävien valmiuksien omaksumista.
}

Yhteiskuntaoppi, poliittinen kiinnittyminen, nuoret, kansalaiskasvatus

Lähetetty: 30.12.2020

Hyväksytty: 28.4.2021

Vastuukirjoittaja: miikka.korventausta@utu.fi

DOI: $10.23988 / \mathrm{ad} .101344$ 


\section{Johdanto}

Ilmastoaktivisti Greta Thunberg aloitti kolme viikkoa kestäneen koululakon elokuussa 2018 ollessaan 15-vuotias. Hän ei mennyt arkipäivisin kouluun, vaan istui Ruotsin valtiopäivätalon edessä vaatien hallitusta vähentämään maan hiilidioksidipäästöjä Pariisin ilmastosopimuksen mukaiselle tasolle (Crouch, 2018). Kokopäiväisen koululakon jälkeen hän yhdessä muiden nuorten kanssa jatkoi lakkoilua aina perjantaisin, mistä syntyi nimitys ilmastoliikkeelle Fridays for Future (https://fridaysforfuture.se/om-oss/). Tammikuussa 2019, viisi kuukautta Thunbergin esimerkin jälkeen, ensimmäiset koululaiset Suomessa lakkoilivat Helsingissä eduskuntatalon edustalla ilmaston puolesta. Tämän jälkeen kului kaksi kuukautta, kunnes Suomessa järjestettiin useilla eri paikkakunnilla mielenilmauksia, joissa jo useat tuhannet nuoret vaativat ilmaston lämpenemisen vastaisia ilmastopoliittisia toimia. Nuoret olivat puolessa vuodessa löytäneet poliittisen osallistumismuodon, jolla vaikuttaa yleiseen mielipideilmastoon sekä asettaa heille tärkeä poliittinen teema, maapallon ja ilmaston tulevaisuus, yhteiskunnallisen keskustelun ja vaikuttamisen agendalle.

Viime aikoina kansainväliseksi ilmiöksi noussut ja Suomessakin nopeassa tahdissa muodostunut nuorten ilmastoliike on viimeisin esimerkki 2010-lukua leimanneesta kehityskulusta, jossa yhteiskunnalliset teemat ovat alkaneet kiinnostaa nuoria aiempaa enemmän. Viimeisimmät Nuorisobarometri-selvitykset ovat antaneet nuorten suhtautumisesta politiikkaan verrattain valoisan kuvan (Pekkarinen \& Myllyniemi, 2019), ja nuorten kiinnostus politiikkaa kohtaan on barometrin mukaan kasvanut 2010-luvulla jatkaen vuosien 2006 ja 2008 notkahdusten jälkeen 1990luvulla alkanutta myönteistä kehitystä. Politiikasta erittäin ja melko kiinnostuneiden määrä 15-29-vuotiaiden ikäluokassa on kasvanut ajanjaksolla 1996-2018 nousten 44 prosentista 64 prosenttiin (Harrinvirta, 2019, s. 117).

2010-luvun tutkimuksissa havaittu suomalaisnuorten kasvava kiinnostus yhteiskunnallisia asioita kohtaan on osaltaan haastanut poliittiseen ja yhteiskunnalliseen kiinnittymiseen liittyvän "huolipuheen", joka on yhdistynyt erityisesti nuorten yhteiskunnallisuutta mittaavien kansainvälisten arviointitutkimusten tuloksiin. Yleishavainto kansainvälisissä ICCS-kyselytutkimuksissa (International Civic and Citizenship Education Study) on ollut, että suomalaisnuoret ovat kansainvälisesti verrattain tietäviä yhteiskunnallisista asioista, mutta heidän halukkuutensa osallistua on ollut matalaa verrattuna muihin osallistujamaihin (Mehtäläinen, NiiloRämä \& Nissinen, 2017; Suoninen, Kupari \& Törmäkangas, 2010). Suomalaista keskustelua on lisäksi pitkään sävyttänyt huoli nuorten matalasta äänestysaktiivisuudesta, sillä uusien sukupolvien äänestyshalukkuus on näyttänyt jäävän pysyvästi aikaisempia sukupolvia matalammaksi (Wass, 2007). Tämäkin kehitys vaikuttaisi jossain määrin olevan taittumassa, sillä vuoden 2019 eduskuntavaaleissa 18-24-vuotiaiden ikäluokassa äänestysprosentti nousi kahdeksan prosenttiyksikköä aikaisempiin 
vaaleihin verrattuna (2015: 47 \%, 2019: 55 \%). Tämä oli samalla suurin äänestysaktiivisuuden kasvu kaikissa tilastoiduissa ikäluokissa.

Nuorten yhteiskunnallisen kiinnostuksen kasvu ajoittuu samalle ajanjaksolle, jolloin valmisteltiin viimeisin perusopetuksen opetussuunnitelmauudistus. Siinä koulun kansalaiskasvatuksen määrää kasvatettiin aikaistamalla yhteiskuntaopin opetus alkamaan vuosiluokilla 4-6. Vuonna 2016 voimaan tullut uudistus oli jatkoa jo edellisen opetussuunnitelmakauden aikana alkaneelle yhteiskuntaopin oppiaineen asemaa vahvistaneelle kehityskululle ja yhtenä sen tavoitteista voidaan pitää nuorten poliittisen ja yhteiskunnallisen kiinnittymisen vahvistamista. Löfströmin, Virran ja Salon (2017, s. 88) mukaan uudistuksen voidaan tulkita myös heijastelleen päättäjien silloista huolta nuorten yhteiskunnallisen kiinnostuksen laimeudesta ja tätä myöten edustuksellisen demokratian legitimiteetistä. On kuitenkin toistaiseksi varsin vähän näyttöä siitä, missä määrin nimenomaisesti peruskoulun yhteiskuntaopin opetus on, ja on ollut, yhteydessä nuorten poliittiseen kiinnittymiseen, vaikka nuorten yhteiskunnallista tietämystä, osallistumista ja asenteita onkin tutkittu (pääosin poikkileikkausaineistoilla).

Tämän tutkimuksen keskeisenä kiinnostuksen kohteena onkin tutkia, miten poliittinen kiinnittyminen ilmenee eri ikäryhmiin kuuluvilla peruskouluikäisillä nuorilla. Taustamotiivina on ajatus yhteiskuntaopin opetuksen mahdollisesta merkityksestä nuorten yhteiskunnalliseen osallisuuteen kasvussa ja nuorten sosiaalistamisessa osaksi demokraattista yhteiskuntaa. Tutkimuksen aineistona hyödynnetään peruskoulun 8.- ja 9.-luokkalaisilta vuosina 2013 ja 2014 kerättyä kyselyaineistoa. Siten tutkimus sijoittuu ajallisesti edellisen, vuosina 2004-2016 voimassa olleen perusopetuksen opetussuunnitelman aikaan, jolloin yhteiskuntaoppia opiskeltiin peruskoulussa käytännössä vain 9. luokalla. Näin ollen tutkimukseen osallistuneet nuoret opiskelivat mittausten välillä lukuvuoden ajan yhteiskuntaoppia ensimmäistä kertaa koulu-urallaan.

\section{Poliittinen kiinnittyminen}

Poliittisen kiinnittymisen tutkimiselle tuo oman lisähaasteensa politiikan käsitteen monitulkintaisuus. Yhtäältä politiikka voidaan käsittää rajatusti valtiollisiin ja hallinnollisiin instituutioihin sekä niiden päätöksenteon paikkoihin kytkeytyvänä areenana, toisaalta sitä voidaan laajemmin pitää myöskin instituutioiden ulkopuolella toteutuvana prosessina, johon sisältyvät monenlaiset neuvottelut, ristiriidat ja muu toiminta liittyen erilaisten resurssien käyttöön ja jakamiseen (Leftwich, 2004). Myös poliittisen kiinnittymisen ja yhteiskunnallisen osallisuuden tutkimukselle on ollut leimallista useiden, sisältönsä puolesta osin päällekkäisten käsitteiden ja teoreettisten viitekehysten käyttö. Tämän tutkimuksen kohteena olevaa poliittisen kiinnittymisen käsitettä (engl. political engagement) on hyödynnetty erilaisia yhteiskunnalliseen osallistumiseen ja vaikuttamiseen sekä yhteiskunnallisiin asenteisiin liittyviä teemoja tutkittaessa. Poliittisen kiinnittymisen lisäksi nuorten kasvamista osaksi yhteiskuntaa on tutkittu osana poliittista sosialisaatiota (Koskimaa \& Rapeli, 2015; Tomperi, 2011) ja yhteiskunnallisen kiinnittymisen (engl. civic engagement) viitekehystä hyödyntäen (Torney-Purta, 2002). Nuoriin kohdistuen aihetta on lisäksi 
tutkittu yksittäisten ulottuvuuksien, kuten poliittisen ja yhteiskunnallisen tietämyksen sekä kiinnostuksen (Elo, 2009) ja politiikkakäsitysten, yhteiskunnallisten taitojen ja asenteiden (Mehtäläinen ym., 2017; Suoninen ym., 2010) näkökulmista.

Merkittävänä nuorten yhteiskunnalliseen ja poliittisen kiinnittymiseen liittyvän kansainvälisen keskustelun vauhdittajana voidaan pitää Robert D. Putnamin (2000) laajasti siteerattua teosta Bowling Alone, jossa nostettiin esiin huoli nuorten yhteiskunnallisen kiinnittymisen heikentymisestä ja yleisestä passivoitumisesta. Näillä nähtiin olevan kielteisiä seurauksia yhteisöllisyydelle sekä amerikkalaisen yhteiskunnan sosiaaliselle pääomalle. Tätä näkemystä on sittemmin kritisoitu ja tulkintaa nuorten passiivisuudesta tarkennettu. Nuoret vaikuttavat haluavan osallistua poliittisesti ja yhteiskunnallisesti, mutta yhteiskunta ei heidän mielestään vastaa tähän kaikuun (Cammaerts, Bruter, Banaji, Harrison \& Anstead, 2014).

Tämän tutkimuksen näkökulmaksi on valittu poliittinen kiinnittyminen, sillä käsitteeseen sisältyy lähikäsitteitä selvemmin näkemys yksilöstä aktiivisena poliittisena toimijana. Tutkimuksessa ehkä yleisimmin, ja toisinaan lähes synonyymina poliittiselle kiinnittymiselle on käytetty yhteiskunnallisen kiinnittymisen käsitettä. Poliittinen kiinnittyminen erotetaan tässä tutkimuksessa kuitenkin yhteiskunnallisesta kiinnittymisestä, joka voidaan nähdä laajempana, erilaisia yhteiskunnallisen osallistumisen tapoja kokoavana käsitteenä, kun taas poliittiseen kiinnittymiseen liittyy poliittisesti suuntautunut toiminta (McCartney, 2013).

Jensenin, Jorban ja Anduizan (2012, s. 3) mukaan poliittisen kiinnittymisen ulottuvuuksia ovat poliittinen osallistuminen, poliittisen informaation kuluttaminen sekä politiikkaan kohdistetut asenteet (ml. kiinnostus, kansalaispätevyys ja arvot). Tässä tutkimuksessa poliittista kiinnittymistä tarkastellaan neljällä näitä ulottuvuuksia operationalisoivalla muuttujalla: 1) poliittinen osallistumishalukkuus, 2) poliittinen tietämys ja itsearvio tietämyksestä, 3) poliittinen kiinnostus, sekä 4) käsitykset politiikasta. Politiikkaan kohdistettuihin asenteisiin lukeutuvan kansalaispätevyyden ja poliittisen tietämyksen välinen yhteys ei ole suoraviivainen, mutta siihen kuuluu kuitenkin yhtenä osana tiedollinen ulottuvuus (Rapeli, 2010), johon tässä tutkimuksessa on haluttu keskittyä rajatummin. Suomalaisnuoria koskevissa tutkimuksissa juuri hyvä poliittisen faktatiedon hallinta, mutta samanaikaisesti matala poliittisen osallistumisen taso, on nostettu dilemmana esiin (Mehtäläinen ym., 2017).

On olennaista huomioida, että poliittinen kiinnittyminen ei ilmiönä tyhjenny pelkkään poliittiseen toimintaan, vaan yksilö voi olla poliittisesti kiinnittynyt myös ilman osallistumista, mikäli hänellä on kiinnostusta, tietoa, mielipiteitä tai asenteita liittyen poliittisiin tai yhteiskunnallisiin aiheisiin. Poliittinen osallistumattomuus ei siis välttämättä tarkoita poliittista kiinnittymättömyyttä, vaan yksilö voi olla poliittisesti kiinnittynyt psykologisella tasolla ilman osallistumisulottuvuutta (Barrett \& Pachi, 2019, s. 3). On lisäksi huomattava, että poliittinen kiinnittyminen on yksilölle vapaaehtoista. Tämä tarkoittaa, että ihmisillä on sekä oikeus osallistua että jättää halutessaan osallistumatta poliittisesti (McIntosh \& Youniss, 2010), minkä myös nuoret ovat halunneet tuoda haastatteluissa esille (Cammaerts ym., 2014). 


\section{Poliittinen osallistuminen ja osallistumishalukkuus}

Poliittinen osallistuminen voidaan määritellä kansalaistoiminnaksi, jolla pyritään vaikuttamaan poliittisiin lopputuotoksiin (Brady, 1999, s. 737). Yhteiskunnallista osallistumista mittaavissa kyselytutkimuksissa on ollut vuosikymmeniä vallalla jaottelu konventionaalisiin (myös: perinteisiin, sovinnaisiin) ja epäkonventionaalisiin (myös: ei-perinteisiin, epäsovinnaisiin) vaikuttamisen tapoihin (ks. esim. Barrett \& Brunton-Smith, 2014), joihin nuorten osallistuminen jaotellaan myös tässä tutkimuksessa. Perinteisellä osallistumisella tarkoitetaan institutionalisoituihin prosesseihin liittyvää toimintaa, kuten vaali- ja äänestysaktiivisuutta sekä puolueisiin linkittyvää osallistumista (Marsh \& Kaase, 1979, s. 84). Ei-perinteinen osallistuminen taas määrittyy instituutioiden ulkopuolella tapahtuvaksi, luonteeltaan epäsäännölliseksi ja vaikeasti ennakoitavaksi aktiivisuudeksi (Bengtsson \& Grönlund, 2005, s. 149), johon voidaan lukea osallistumistapoja kuten mielenosoittaminen, kansalaisaktivismi ja internetin kautta tapahtuva osallistuminen.

Aiemmin epäkonventionaalisina pidettyjen osallistumistapojen tultua suositummiksi on esitetty, ettei edellä mainitun jaottelun ylläpito ole enää perusteltua (Teorell, Torcal \& Montero, 2007). Suomalaisessa keskustelussa esimerkiksi Eränpalo (2012) on kritisoinut kansainvälisten vertailututkimusten tulosten tulkintaa painottamalla, että niissä osallistuminen käsitetään kapeana, ja perinteisten vaikutusväylien ulkopuolinen aktiivisuus sivuutetaan. Tässä tutkimuksessa ollaan kiinnostuneita 8.- ja 9.-luokkalaisten nuorten poliittisen osallistumishalukkuuden eroista yksittäisten osallistumismuotojen osalta. Samalla halutaan kuitenkin selvittää, näkyykö osallistumishalukkuudessa eroja niin kutsuttujen perinteisten ja ei-perinteisen osallistumismuotojen välillä.

\section{Poliittinen tietämys}

Poliittisella tietämyksellä tarkoitetaan Delli Carpinin ja Keeterin (1996, s. 10) yleisesti käytetyn määritelmän mukaisesti politiikkaan liittyvää faktatietoa, joka on tallentunut pitkäkestoiseen muistiin. Heidän mukaansa poliittiseen tietämykseen liittyvä tietoulottuvuus (engl. information) erottaa sen poliittisista mielipiteistä. Toisin sanoen poliittisella tietämyksellä tarkoitetaan politiikkaa koskevien tosiasioiden hallintaa (Milner, 2002, s. 53; ks. myös Rapeli, 2013).

Poliittinen tietämys auttaa kansalaisia ymmärtämään yhteiskunnan ja sen instituutioiden toimintaa. Mitä enemmän kansalaisilla on tietoa politiikasta, sitä paremmin he kykenevät ymmärtämään poliittisten päätösten vaikutuksia itseään koskeviin asioihin sekä edistämään toivomiaan asioita poliittisessa prosessissa. Kansalaisten olisi tärkeää omaksua poliittisen tietämyksen perustaso, koska muuten heidän on vaikea ymmärtää poliittisia tapahtumia sekä yhdistää uutta informaatiota aikaisempaan. Tällaisen perustason saavuttamisen voidaan ajatella olevan myös perusopetuksen tehtävä: yhteiskunnallisen tietämyksen perustaso, jotta kansalaisena pystyy seuraamaan ja osallistumaan yhteiskunnalliseen toimintaan (Galston, 2001).

Poliittista tietämystä on Suomessa tutkittu laajasti osana Yhteiskuntatutkimus 2008 -kyselyä, jossa havaittiin, että täysi-ikäisten poliittista ja yhteiskunnallista tietämystä voitiin pitää vähintäänkin kohtuullisena. 
Vastaajien tiedot tutkimuksessa mitatuilla osa-alueilla - Suomen poliittinen järjestelmä, EU ja kansantalous - vaihtelivat kuitenkin suuresti (Elo \& Rapeli, 2008). Samoihin aikoihin tutkittiin myös toisen asteen opiskelijoiden poliittista tietämystä, ja havaittiin, että ammattioppilaitoksissa opiskelevat menestyivät kautta linjan heikommin poliittista tietämystä mitanneissa kysymyksissä kuin lukioissa opiskelevat nuoret (Elo, 2009).

Nuorten yhteiskunnallista tietämystä on lisäksi aiemmin tutkittu suomalaisessa kontekstissa osana kansainvälisiä ICCS-kyselytutkimuksia, joissa yhteiskunnallisella tiedolla on tarkoitettu faktatiedon lisäksi myös tiedon soveltamista käytäntöön, ymmärtämistä, analysointia ja päättelemistä (Mehtäläinen ym., 2017, s. 19). Näissä tutkimuksissa suomalaisnuorten yhteiskunnallinen tietämys on näyttäytynyt 2010-luvun taitteessa vertailuaineiston korkeimpana (Suoninen ym., 2010) ja viimeisimmässä, vuoden 2016 ICCS-tutkimuksessa neljänneksi korkeimpana (Mehtäläinen ym., 2017).

\section{Poliittinen kiinnostus ja käsitykset politiikasta}

Poliittinen kiinnostus kertoo siitä, missä määrin politiikka herättää kansalaisten mielenkiintoa (van Deth, 1990, s. 278). Toisin sanoen sillä tarkoitetaan kansalaisten yleistä kiinnostusta yhteiskunnallisiin asioihin ja niiden hoitamiseen (Kestilä-Kekkonen, 2015, s. 52). Poliittisella kiinnostuksella on havaittu olevan yhteys esimerkiksi poliittiseen tietämykseen: kiinnostuneiden toisen asteen opiskelijoiden keskuudessa poliittisen tietämyksen tason on havaittu olleen korkeampi kuin politiikasta ei-kiinnostuneiden tietämyksen tason (Elo, 2009).

Suomalaisnuorten poliittista kiinnostusta mittaavan vuosittaisen Nuorisobarometri-selvityksen mukaan nuorten kiinnostus politiikkaa kohtaan on kasvanut 1990-luvulta lähtien lukuun ottamatta notkahdusta vuosina 2006 ja 2008. Viimeisimmässä asiaa selvittäneessä vuoden 2018 Nuorisobarometrissä politiikasta erittäin ja ainakin jonkin verran kiinnostuneiden määrä oli yhteensä $65 \%$ tutkimukseen vastanneista. Samaan aikaan vain vähän ja ei lainkaan kiinnostuneiden määrä oli yhteensä $35 \%$ (Pekkarinen \& Myllyniemi, 2019). Viimeisessä poliittista kiinnostusta mitanneessa ICCS-vertailututkimuksessa suomalaisnuorten kiinnostus on jäänyt kuitenkin selvästi alle eurooppalaisten maiden keskiarvon (Suoninen ym., 2010).

Kuten jo aiemmin todettiin, poliittista kiinnostusta kysyttäessä on tärkeää huomioida, että itse käsite politiikka voidaan ymmärtää lukuisin eri tavoin ja siihen voidaan liittää erilaisia mielikuvia. Poliittisen osallistumishalukkuuden, faktatietämyksen ja kiinnostuksen lisäksi tässä tutkimuksessa ollaan kiinnostuneita myös siitä, millaisena ilmiönä nuoret itse käsittävät politiikan. Millaista on siis se politiikka, johon tutkimukseen osallistujat suhteuttavat vastauksensa? Tässä tutkimuksessa nuorten käsityksiä politiikasta tutkittiin samoilla monivalintaväittämillä kuin aikaisemmassa Suomalaisten politiikkatietämys -tutkimuksessa, jossa täysiikäisten käsitykset politiikasta näyttäytyivät melko myönteisinä, ja politiikka käsitettiin yhteisenä toiminta-areenana, jossa päätetään kaikkia koskevista asioista (Elo \& Rapeli, 2008, s. 61). 


\section{Koulutuksen ja yhteiskuntaopin merkitys nuorten poliittiseen kiin- nittymiseen}

Poliittinen kiinnittyminen tapahtuu osana yksilön poliittista sosialisaatioprosessia, jolla Eastonin ja Dennisin (1969, s. 24-25) perinteisen määritelmän mukaan tarkoitetaan tapoja, joilla yhteiskunta siirtää poliittisia asenteita, normeja, arvoja ja tietämystä sukupolvelta toiselle. Yhteiskunnan instituutiona koululla on yhteiskunnallisia tehtäviä, jotka määrittävät sen toimintaa ja joista osaa voidaan pitää universaaleina, kaikille yhteiskunnille yhteisinä. Yhteiskunnan kiinteyden ja jatkuvuuden kannalta koulun keskeinen yhteiskunnallinen tehtävä on poliittinen sosialisaatio, uuden sukupolven integrointi yhteiskunnan arvoihin sekä institutionaalisiin toimintakäytäntöihin. Poliittista sosialisaatiota tapahtuu koulussa julkilausutusti ja piilo-opetussuunnitelman (Meighan \& Harber, 2007) välityksellä.

Virallisen koulun näkökulmasta keskeistä on se, millaista osallistumista opetussuunnitelma painottaa sekä mitkä ovat opetukselliset ja oppimiseen liittyvät tavoitteet. Erityisesti koulun kansalaiskasvatuksella (engl. civic education, citizenship education), jonka voidaan pitkälti nähdä vastaavan käsitettä yhteiskunnallinen kasvatus (Löfström, Virta \& Salo, 2017), on kansainvälisessä tutkimuksessa havaittu olevan tärkeä rooli poliittisen tietämyksen ja kiinnostuksen kehittymisessä (Galston, 2001; Niemi \& Junn, 1998). On myös viitteitä siitä, että erilaiset kansalaiskasvatuksen opetusmuodot ovat yhteydessä erilaisiin lopputulemiin. Esimerkiksi formaalilla opetuksella, jossa korostuvat sisällöt liittyen poliittisiin instituutioihin ja tapahtumiin, on havaittu olevan yhteys kansalaispätevyyden ja poliittisen kiinnostuksen myönteiseen kehittymiseen (Dassonneville, Quintelier, Hooghe \& Claes, 2012). Oppituntikeskustelujen avoimuudella taas on havaittu olevan myönteinen vaikutus nuorten yhteiskunnalliseen tietämykseen ja halukkuuteen äänestää täysi-ikäisenä (Campbell, 2008). Oppilaiden omaa toimintaa painottavalla projektityöskentelyllä taas on saatu lupaavia tuloksia liittyen nuorten osallistumishalukkuuden kasvuun (Andolina \& Conklin, 2018).

Vaikka koulutuksella vaikuttaisi siis olevan merkitystä nuorten poliittisessa kiinnittymisessä, näyttäisi kodin ja ystäväpiirin rooli poliittisessa sosialisaatiossa olevan kuitenkin koulutusta merkittävämpi, kun nämä eri sosialisaation kontekstit otetaan yhdessä huomioon nuorten poliittista kiinnostusta tutkittaessa (Koskimaa \& Rapeli, 2015). Toisaalta on havaittu viitteitä siitä, että koulutus voisi tukea erityisesti niiden nuorten poliittista kiinnittymistä, joilla vanhempien kautta tapahtuva poliittinen sosialisaatio on heikkoa (ns. kompensaatioefekti; Neundorf, Niemi \& Smets, 2016). Eri sosialisaatioympäristöjen yhteisvaikutusta ja koulun kompensaatioefektin merkitystä nuorten poliittisen kiinnittymisen eri ulottuvuuksiin olisi kuitenkin tarpeellista tutkia vielä enemmän.

Kansalaiskasvatusta järjestetään eri koulutusjärjestelmissä eri tavoin, mutta Suomessa se linkittyy vahvimmin, joskaan ei pelkästään, yhteiskuntaopin oppiaineeseen, jota opetettiin pitkään 1900-luvulla osana kaksoisainetta historia ja yhteiskuntaoppi. Yhteiskuntaoppi kuitenkin erotettiin omaksi oppiaineekseen vuonna 2004 käyttöön otetussa perusopetuksen opetussuunnitelmassa (Opetushallitus, 2004), jonka voimassaoloaikaan tämän tutkimuksen aineistonkeruu ajoittuu. Onkin olennaista 
pohjustaa tutkimus tarkastelemalla vielä sen kansalaiskasvatuksellisia tavoitteita ja sisältöjä erityisesti yhteiskuntaopin oppiaineessa, johon tutkimuksen aihe vahvimmin linkittyy.

Nykyistä edeltäneessä, vuosina 2004-2016 voimassa olleessa opetussuunnitelmassa perusopetukselle esitettiin tehtäväksi antaa oppilaalle mahdollisuus "osallistuvana kansalaisena kehittää demokraattista yhteiskuntaa" (Opetushallitus, 2004, s. 14). Yhteiskuntaopin oppiaineen tarkoituksena oli opetussuunnitelman mukaan "tukea oppilaan kasvua suvaitsevaiseksi ja demokraattiseksi kansalaiseksi ja antaa hänelle kokemuksia yhteiskunnallisesta osallistumisesta ja demokraattisesta vaikuttamisesta." Näihin liittyen oppilaalle asetettiin tavoitteeksi kiinnostua "yhteiskunnallisesta osallistumisesta ja vaikuttamisesta" sekä oppia "tarkastelemaan ja kehittämään osaamistaan vastuullisena kuluttajana ja yhteiskunnallisena toimijana." Sisältöinä näiden tavoitteiden omaksumiseksi käsiteltiin esimerkiksi "vaikuttamista ja päätöksentekoa" mukaan lukien a) kansalaisten mahdollisuudet vaikuttaa, b) demokratia, vaalit ja äänestäminen, c) politiikan ja hallinnon toimijat kunnallisella, valtakunnallisella ja EU-tasolla sekä d) media ja yhteiskunnallinen vaikuttaminen (Opetushallitus, 2004, s. 228-229).

Vuosina 2004-2016 voimassa olleessa opetussuunnitelmassa useisiin oppiaineisiin linkittyvänä aihekokonaisuutena oli lisäksi "osallistuva kansalaisuus ja yrittäjyys", jonka päämääränä oli "auttaa oppilasta hahmottamaan yhteiskuntaa eri toimijoiden näkökulmista ja kehittää osallistumisessa tarvittavia valmiuksia sekä luoda pohjaa yrittäjämäisille toimintatavoille". Koulun oppimiskulttuurin ja toimintatapojen tuli "tukea oppilaan kehittymistä omatoimiseksi, aloitteelliseksi, päämäärätietoiseksi, yhteistyökykyiseksi ja osallistuvaksi kansalaiseksi sekä tukea oppilasta muodostamaan realistinen kuva omista vaikutusmahdollisuuksistaan." (Opetushallitus, 2004, s. 40).

\section{Tutkimuskysymykset, aineisto ja menetelmät}

Tässä tutkimuksessa haetaan vastauksia seuraaviin tutkimuskysymyksiin:

1. Minkälaisena näyttäytyy peruskoulun 8.- ja 9.-luokkalaisten nuorten poliittinen kiinnittyminen sekä

2. minkälaisia eroja on näiden ikäryhmien poliittisessa kiinnittymisessä, kun tarkastelun kohteena ovat

a) poliittinen kiinnostus

b) poliittinen tietämys ja itsearvio tietämyksestä

c) poliittinen osallistumishalukkuus

d) käsitykset politiikasta?

Tutkimusaineistona on yhden varsinaissuomalaisen yläkoulun oppilaiden vastaukset poliittista kiinnittymistä mittaavaan anonyymiin kyselyyn kahtena eri ajankohtana. Vastaajat olivat ensimmäisenä tutkimusajankohtana (helmikuu 2013) 8.-luokkalaisia ja toisena tutkimusajankohtana (toukokuu 2014) 9.-luokkalaisia. Vastaajat opiskelivat vastausajankohtien välillä lukuvuoden ajan yhteiskuntaoppia ensimmäistä kertaa 
koulu-urallaan (yhteiskuntaopin oppiainetta opiskeltiin vuosina 20042016 voimassa olleen opetussuunnitelman aikana käytännössä vain yhdeksännellä luokalla). 8.-luokkalaisten kyselyyn vastasi 67 nuorta ja 9.luokkalaisten kyselyyn 63 nuorta. Vastausprosentit koulun kaikkiin 8.- ja 9.-luokkalaisiin suhteutettuna olivat $87 \%$ (8. 1k: yht. 77 oppilasta) ja $81 \%$ (9. lk: yht. 77 oppilasta). Kyselyyn vastanneet nuoret olivat mittausajanjakson aikana 14-16-vuotiaita.

\section{Poliittisen kiinnittymisen operationalisointi}

Kysely toteutettiin soveltamalla lomaketta, jolla oli aiemmin mitattu suomalaisten täysi-ikäisten (Elo \& Rapeli, 2008) ja toisen asteen lukio- ja ammatti-instituuttiopiskelijoiden (Elo, 2009) poliittista tietämystä sekä yhteiskunnalliseen kiinnittymiseen liittyviä taustamuuttujia. Kysymysasetteluja muokattiin paremmin soveltuvaksi nuorille vastaajille, ja mittaria täydennettiin lisäämällä siihen kysymys nuorten suhtautumisesta politiikan ja yhteiskunnallisten asioiden opetukseen koulussa. Poliittinen kiinnittyminen jaettiin tutkimuksessa neljään eri ulottuvuuteen: poliittiseen kiinnostukseen, poliittiseen tietämykseen ja itsearvioon tietämyksestä, poliittiseen osallistumishalukkuuteen ja käsityksiin politiikasta. Näiden lisäksi tutkittiin vastaajien käsityksiä eri tietolähteiden merkityksestä heidän saamaansa yhteiskunnalliseen tietoon.

Poliittista kiinnostusta tutkimuksessa mitattiin yhdellä kysymyksellä Kuinka kiinnostunut olette politiikasta?, johon oli mahdollisuus vastata neliportaisesti ( 1 = en lainkaan kiinnostunut; 4 = erittäin kiinnostunut). Lisäksi oli mahdollisuus vastata "en osaa sanoa".

Poliittista tietämystä mitattiin viidellä kysymyksellä, jotka valikoitiin lomakkeen laajasta politiikkatietämystä mittaavasta kysymyspatteristosta. Kysymysten valinnan perusteena oli, että ne mittaavan perustavanlaatuisia asioita liittyen eri politiikan osa-alueisiin: 1) vaaleihin, 2) hallitukseen, 3) eduskuntaan, 4) presidentti-instituutioon, ja 5) verotuksen periaatteisiin (ks. taulukko 1). Jokaiseen kysymykseen oli yksi oikea vastaus. Vastaukset pisteytettiin (oikea vastaus: 1 piste, väärä / tyhjä vastaus: 0 pistettä) ja oikeiden vastausten lukumäärästä muodostettiin vastaajille poliittisen tietämyksen tunnusluku välillä 0-5. Ennen tietämyskysymyksiä vastaajilta kysyttiin heidän itsearviotaan omasta poliittisten ja yhteiskunnallisten asioiden tietämyksestä. Kysymykseen Miten hyvin itse arvioit tuntevasi politiikkaa ja yhteiskunnallisia asioita? oli mahdollisuus vastata viisiportaisesti ( $1=$ heikosti; $5=$ erittäin hyvin). Lisäksi oli mahdollisuus vastata "en osaa arvioida".

Poliittista osallistumishalukkuutta mitattiin kysymällä vastaajilta Mitä seuraavista voisit pitää itsellesi mielekkäänä tapana osallistua yhteiskunnallisesti? Alkuperäisessä kyselylomakkeessa (Elo \& Rapeli, 2008) yhtenä osiona oli poliittinen osallistuminen, jota operationalisoitiin kysymällä vastaajilta Mitä seuraavista pidätte itsellenne mielekkäänä tapana osallistua yhteiskunnallisesti? Tässä tutkimuksessa kysymys muutettiin koskemaan osallistumishalukkuutta, koska vastaajilla ei heidän alaikäisyydestään johtuen ollut vielä mahdollisuutta osallistua kaikilla kysytyillä osallistumismuodoilla kuten äänestämällä. Kysymykseen liittyen lueteltiin kymmenen yhteiskunnallista osallistumismuotoa, joihin oli 
mahdollisuus vastata neliportaisesti $(1$ = en lainkaan mielekkäänä; 4 = erittäin mielekkäänä). Osallistumismuodot jaettiin aineiston analyysissa edelleen kahteen summamuuttujaan: perinteisiin (cronbachin alfa $=0,74$ ) ja ei-perinteisiin osallistumismuotoihin (cronbachin alfa $=0,66$ ), jotka molemmat koostuivat viiden (5) kysymyksen perusteella lasketuista summamuuttujista (ks. taulukko 2).

Nuorten käsityksiä politiikasta kartoitettiin seitsemällä väittämällä (ks. taulukko 3). Näitä kysymyksiä käsiteltiin aineiston analyysivaiheessa yksittäin, koska erilaisten käsitysten pelkistämistä summamuuttujiksi ei nähty mielekkäänä. Väittämiin oli mahdollista vastata neliportaisesti sen perusteella, miten väite sopii vastaajan käsityksiin aiheesta $(1=$ sopii erittäin huonosti; 4 = sopii erittäin hyvin). Lisäksi oli mahdollisuus vastata "en osaa sanoa".

Nuorten näkemyksiä koulun ja muiden lähteiden merkityksestä saamaansa yhteiskunnalliseen tietoon mitattiin kysymällä vastaajilta Millaisen tietotason yhteiskunnallisten asioiden ymmärtämiseksi katsot saaneesi a) koulussa, b) kotona, c) ystävä-ja/tai tuttavapiirissä ja d) itseopiskelun kautta? Kuhunkin neljään ympäristöön liittyen oli mahdollista antaa vastaus viisiportaisesti ( 1 = en mitään; $5=$ erittäin hyvän).

Lisäksi nuorten suhtautumista politiikan ja yhteiskunnallisten asioiden opetukseen koulussa mitattiin kolmella väittämällä: Koen saaneeni koulussa tarpeeksi tietoa politiikasta ja yhteiskunnallisista asioista, Koulussa käsitellään liikaa politiikkaa ja yhteiskunnallisia asioita sekä Koulussa pitäisi käsitellä enemmän politiikkaa ja yhteiskunnallisia asioita. Väittämiin oli mahdollisuus vastata neliportaisesti ( 1 = täysin eri mieltä; 4 = täysin samaa mieltä).

\section{Tilastolliset analyysit}

Kyselyt toteutettiin anonyymisti, koska vastaajat olivat alaikäisiä ja kyselyissä käsiteltiin sensitiivisiä tietoja liittyen heidän poliittisiin asenteisiinsa. Tästä syystä vastaajien vastauksia kahtena eri ajankohtana (8. ja 9. luokka) ei ollut mahdollista yhdistää, ja aineisto analysoitiin riippumattomia ryhmiä vertailevilla testeillä. Tässä yhteydessä on syytä myös huomioida, että vertailtujen luokka-asteiden aineistossa oli todennäköisesti useita samoja vastaajia, koska aineiston keruu tapahtui samassa koulussa peräkkäisinä vuosina. Analyysit toteutettiin käyttämällä epäparametrisiä testejä, koska mitattavat muuttujat olivat järjestysasteikollisia. Vastemuuttujien ollessa järjestysasteikollisia analyysit toteutettiin Mann-Whitneyn U-testillä ja dikotomisten vastamuuttujien kohdalla käytettiin khiin neliö -testiä. Lisäksi perinteisen ja ei-perinteisen osallistumishalukkuuden eroja luokka-asteittain analysoitiin Wilcoxonin testillä, kun taas eri lähteiden merkitystä nuorten saamaan yhteiskunnalliseen tietoon arvioitiin Friedmanin testillä ja tähän liittyvät parittaisvertailut toteutettiin Durbinin ja Conoverin kehittämällä testillä. 


\section{Tulokset}

\section{Poliittinen kiinnostus}

9.-luokkalaisten $(\mathrm{ka}=2,34, \mathrm{kh}=0,73)$ poliittinen kiinnostus oli tilastollisesti merkitsevästi korkeampaa kuin 8.-luokkalaisten $(\mathrm{ka}=1,95$, $\mathrm{kh}=0,87), \mathrm{z}=-2,630, \mathrm{p}=0,009, \mathrm{r}=0,27$. Tuloksia tarkasteltiin lisäksi vertailemalla vastausten suhteellisia osuuksia. Politiikasta erittäin kiinnostuneiden osuus oli molemmissa ikäluokissa vähäinen ( $3 \%$ ja 3,2 \%), ja erot ilmenivät muiden vastauskategorioiden kohdalla. Suhteellisesti suurin ero ikäluokkien välillä oli politiikasta ei lainkaan kiinnostuneiden kohdalla, joihin lukeutui 8 . luokalla $31,3 \%$ ja 9 . luokalla $11,1 \%$ vastaajista. Politiikasta jonkin verran kiinnostuneiden osuus oli 9. luokalla 15,6 prosenttiyksikköä, ja vain vähän kiinnostuneiden osuus 11,6 prosenttiyksikköä, korkeampi kuin 8. luokalla (kuvio 1).

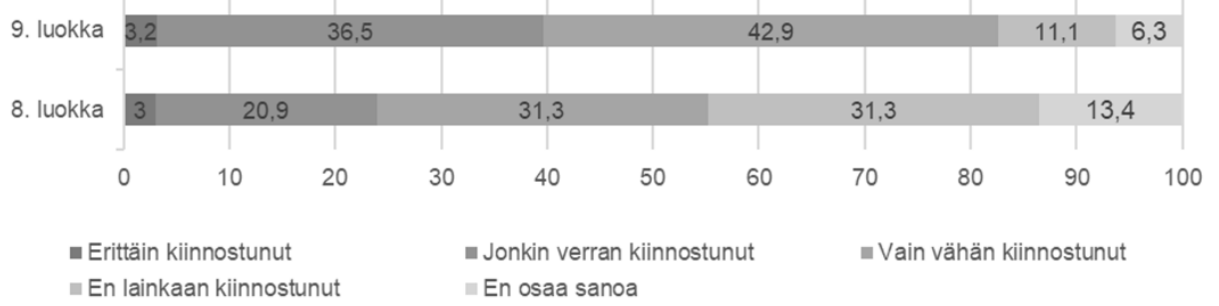

Kuvio 1. Kahdeksas- ja yhdeksäsluokkalaisten poliittinen kiinnostus

\section{Poliittinen tietämys}

Nuorten poliittista tietämystä lähestyttiin tutkimuksessa sekä nuorten itsearvioinnin että faktatiedon hallinnan näkökulmista. 9.-luokkalaisten vastaukset osoittautuivat näissä molemmissa merkitsevästi korkeammiksi 8.-luokkalaisiin verrattuna (itsearvio: $\mathrm{z}=-3,899, \mathrm{p}<0,001, \mathrm{r}=0,41$; mitattu tietämys: $\mathrm{z}=-5,998, \mathrm{p}<0,001 ; \mathrm{r}=0,60)$. 9.-luokkalaiset arvioivat (asteikolla 1-5) tietonsa keskimäärin melko hyväksi $(\mathrm{ka}=2,84, \mathrm{kh}=0,91)$, kun taas 8.-luokkalaiset arvioivat tietämyksensä selvästi heikommiksi $(\mathrm{ka}=2,14, \mathrm{kh}=0,95)$. Varsinaisessa testissä 9.-luokkalaiset vastasivat viidestä kysymyksestä oikein keskimäärin 3,22 ( $\mathrm{kh}=1,33)$, ja 8.-luokkalaisten keskiarvo oli 1,69 $(\mathrm{kh}=1,18)$. 
Ainedidaktiikka 5(1) (2021)

Taulukko 1. Kahdeksas- ja yhdeksäsluokkalaisten poliittinen tietämys

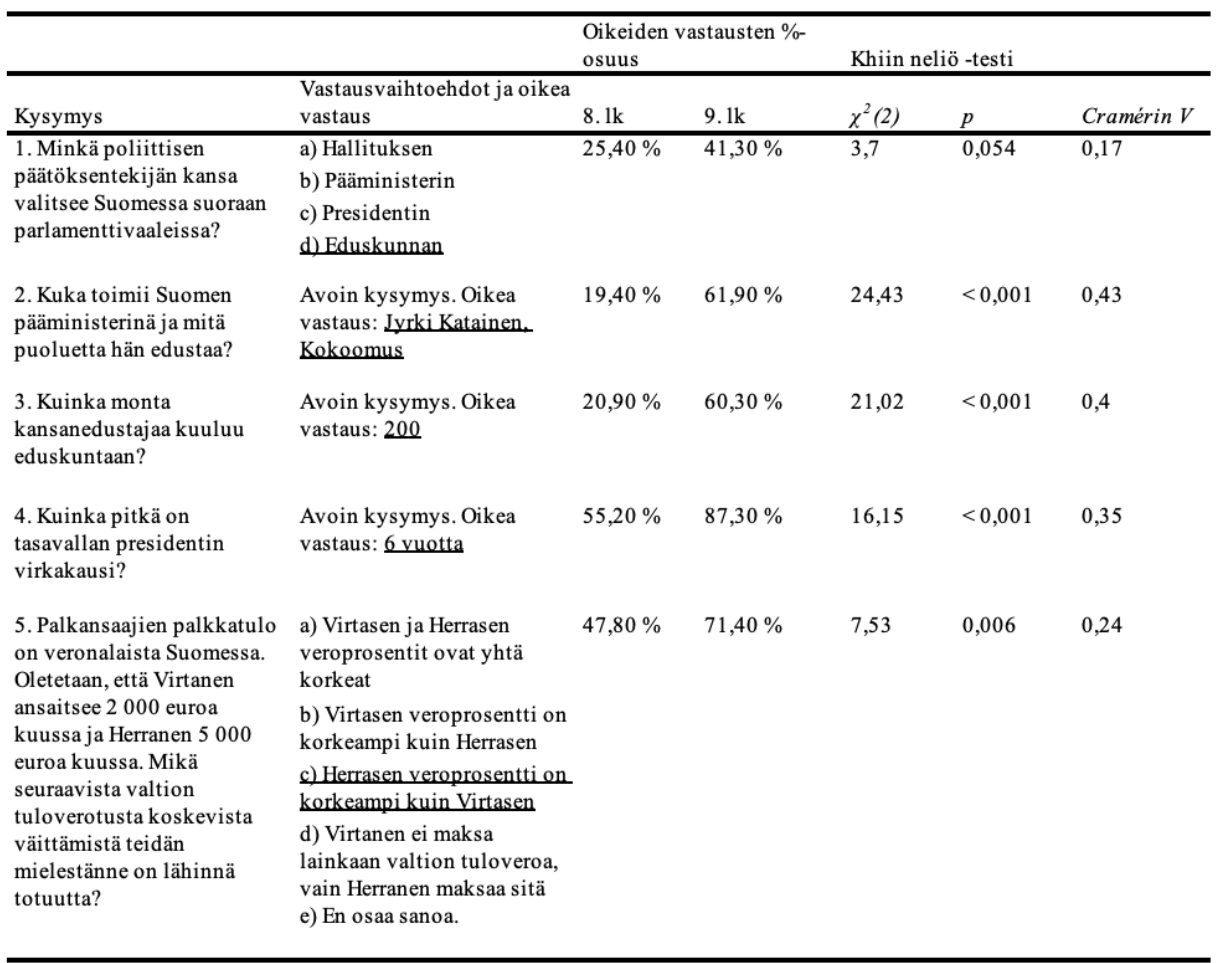

Keskiarvojen lisäksi tutkittiin, miten nuoret vastasivat yksittäisiin kysymyksiin (ks. taulukko 1). 9.-luokkalaisten nuorten tietämyksen havaittiin olevan systemaattisesti parempaa kaikkien viiden väittämän kohdalla. 8.-luokkalaiset tiesivät parhaiten, kuinka pitkä on tasavallan presidentin virkakausi (55,2 \% oikeita vastauksia), ja heikoiten, kuka toimi Suomen pääministerinä ja mitä puoluetta hän edusti (20,9 \%). 9.-luokkalaiset tiesivät myös parhaiten presidentin virkakauden pituuden $(87,3 \%)$, kun taas heikoimmin, minkä poliittisen päätöksentekijän kansa valitsee Suomessa suoraan parlamenttivaaleissa $(41,3 \%)$.

\section{Poliittinen osallistumishalukkuus}

Poliittisessa osallistumishalukkuudessa ei havaittu merkitseviä eroja luokka-asteiden välillä ( $p>0,05$; taulukko 2). Kun verrattiin eroja halukkuudessa osallistua perinteisillä ja ei-perinteisillä tavoilla, havaittiin, että halukkuus osallistua perinteisillä tavoilla oli tilastollisesti vahvempaa molemmissa ikäryhmissä $(\mathrm{p}<0,001)$.

Vaikka jo summamuuttujien analyysi osaltaan osoitti, että osallistumishalukkuuden erot olivat ikäluokkien välillä vähäisiä, haluttiin kiinnittää huomiota myös yksittäisiin osallistumismuotoihin (ks. taulukko 2). Yhdenkään osallistumismuodon osalta ei kuitenkaan havaittu tilastollisesti merkitseviä eroja ikäluokkien välillä $(\mathrm{p}>0,05)$. Sekä 8. että 9. luokalla vaaleissa äänestäminen oli keskiarvoltaan mielekkäin osallistumismuoto, kun taas kansalaisaktivismia ei pidetty juurikaan mielekkäänä. On merkille pantavaa, että perinteisissä osallistumismuodoissa puolueen tai muun poliittisen järjestön toimintaan osallistuminen oli vähiten suosittu vaihtoehto. Sen sijaan ei-perinteisistä osallistumismuodoista internetin kautta tapahtuva osallistuminen erottui olemalla kaikista vaihtoehdoista toiseksi suosituin osallistumismuoto vaaleissa äänestämisen jälkeen. 
Ainedidaktiikka 5(1) (2021)

Taulukko 2. Kahdeksas- ja yhdeksäsluokkalaisten poliittinen osallistumishalukkuus

\begin{tabular}{|c|c|c|c|c|c|c|c|c|c|c|}
\hline \multicolumn{3}{|c|}{ 8. $\mathrm{kk}$} & \multicolumn{3}{|c|}{ 9. $\mathrm{lk}$} & \multicolumn{5}{|c|}{ Mann-Whitneyn U-testi } \\
\hline Kysymys & $n$ & $k a$ & $k h$ & $n$ & $k a$ & $k h$ & $\bar{U}$ & $z$ & $p$ & $r$ \\
\hline Perinteinen osallistuminen & 67 & 2,16 & 0,61 & 63 & 2,2 & 0,54 & 1998 & $-0,527$ & 0,598 & 0,05 \\
\hline $\begin{array}{l}\text { Mielipidekirjoituksen } \\
\text { kirjoittaminen }\end{array}$ & 67 & 2,16 & 0,9 & 63 & 2,05 & 0,92 & 1995,5 & $-0,76$ & 0,447 & 0,05 \\
\hline Äänestäminen vaaleissa & 67 & 2,91 & 0,81 & 63 & 3,17 & 0,87 & 1721,5 & $-1,921$ & 0,055 & 0,18 \\
\hline $\begin{array}{l}\text { Yhteydenotto } \\
\text { päätöksentekijään }\end{array}$ & 67 & 1,91 & 0,79 & 63 & 1,97 & 0,8 & 2016 & $-0,471$ & 0,637 & 0,04 \\
\hline $\begin{array}{l}\text { Vaalikampanjaan } \\
\text { osallistuminen }\end{array}$ & 66 & 2,05 & 2,05 & 63 & 2,02 & 0,81 & 2065 & $-0,7$ & 0,944 & 0,01 \\
\hline $\begin{array}{l}\text { Puolueen tai muun } \\
\text { poliittisen järjestön } \\
\text { toimintaan osallistuminen }\end{array}$ & 66 & 1,79 & 0,75 & 63 & 1,79 & 0,68 & 2026,5 & $-0,272$ & 0,786 & 0,03 \\
\hline $\begin{array}{l}\text { Ei-perinteinen } \\
\text { osallistuminen }\end{array}$ & 67 & 1,9 & 0,59 & 63 & 1,97 & 0,53 & 1891 & $-1,029$ & 0,303 & 0,10 \\
\hline $\begin{array}{l}\text { Muuhun kuin poliittiseen } \\
\text { järjestö- tai } \\
\text { yhdistystoimintaan } \\
\text { osallistuminen }\end{array}$ & 67 & 1,91 & 0,79 & 63 & 1,97 & 0,8 & 2016 & $-0,471$ & 0,637 & 0,04 \\
\hline $\begin{array}{l}\text { Mielenosoitukseen } \\
\text { osallistuminen }\end{array}$ & 67 & 1,82 & 0,98 & 63 & 1,81 & 0,82 & 2051 & $-0,299$ & 0,765 & 0,03 \\
\hline Protestiäänestäminen & 66 & 1,8 & 0,86 & 62 & 1,85 & 0,83 & 1951 & $-0,485$ & 0,628 & 0,05 \\
\hline Kansalaisaktivismi & 67 & 1,51 & 0,7 & 63 & 1,52 & 0,72 & 2087 & $-0,126$ & 0,9 & 0,01 \\
\hline $\begin{array}{l}\text { Internetin kautta tapahtuva } \\
\text { osallistuminen }\end{array}$ & 67 & 2,45 & 0,8 & 63 & 2,67 & 0,97 & 1821 & $-1,421$ & 0,155 & 0,14 \\
\hline
\end{tabular}

\section{Käsitykset politiikasta}

Nuorten käsitykset politiikasta olivat molemmilla luokka-asteilla keskimäärin myönteisiä ja likipitäen samankaltaisia (taulukko 3). Ainoastaan väitteen "politiikka on julkista toimintaa" kohdalla käsitykset erosivat tilastollisesti merkitsevästi, ja 9.-luokkalaiset samastuivat väitteeseen vahvemmin. Parhaiten politiikkaa kuvasi sekä 8.- että 9.-luokkalaisten nuorten mielestä väittämä "politiikka vaikuttaa tavallisen ihmisen elämään". Heikoiten nuoret samastuivat väitteeseen "politiikassa on kyse ainoastaan henkilökohtaisen hyödyn tavoittelusta".

Taulukko 3. Kahdeksas- ja yhdeksäsluokkalaisten käsitykset politiikasta

\begin{tabular}{|c|c|c|c|c|c|c|c|c|c|c|}
\hline & $8 \mathrm{lk}$ & & & $9 \mathrm{lk}$ & & & Mann-И & aitneyn L & testi & \\
\hline Väite & $n$ & $\mathrm{ka}$ & $k h$ & $n$ & $k a$ & $k h$ & $U$ & $Z$ & $p$ & $r$ \\
\hline $\begin{array}{l}\text { Politiikassa on kyse } \\
\text { ainoastaan } \\
\text { henkilökohtaisen } \\
\text { hyödyn tavoittelusta }\end{array}$ & 52 & 1,94 & 0,89 & 52 & 1,77 & 0,76 & 1229 & $-0,855$ & 0,393 & 0,09 \\
\hline $\begin{array}{l}\text { Politiikka on julkista } \\
\text { toimintaa }\end{array}$ & 60 & 3,15 & 0,63 & 59 & 3,39 & 0,53 & 1433 & $-2,049$ & 0,04 & 0,19 \\
\hline $\begin{array}{l}\text { Politiikka on yhteisten } \\
\text { asioiden hoitamista }\end{array}$ & 60 & 3,3 & 0,79 & 59 & 3,44 & 0,53 & 1670,5 & $-0,587$ & 0,557 & 0,06 \\
\hline $\begin{array}{l}\text { Politiikka on kilpailua } \\
\text { vallasta }\end{array}$ & 55 & 2,45 & 0,94 & 57 & 2,51 & 0,71 & 1479,5 & $-0,547$ & 0,584 & 0,06 \\
\hline $\begin{array}{l}\text { Politiikan sisältöön } \\
\text { vaikuttaminen } \\
\text { edellyttää osallistumista }\end{array}$ & 52 & 2,94 & 0,85 & 57 & 3,23 & 0,68 & 1216,5 & $-1,794$ & 0,073 & 0,18 \\
\hline $\begin{array}{l}\text { Politiikka on } \\
\text { ristiriitojen } \\
\text { ratkaisemista }\end{array}$ & 51 & 2,82 & 0,87 & 55 & 3,02 & 0,73 & 1247,5 & $-1,098$ & 0,272 & 0,11 \\
\hline $\begin{array}{l}\text { Politiikka vaikuttaa } \\
\text { tavallisen ihmisen } \\
\text { elämään }\end{array}$ & 54 & 3,2 & 0,86 & 56 & 3,48 & 0,69 & 1244,5 & $-1,768$ & 0,077 & 0,18 \\
\hline
\end{tabular}

${ }^{\text {a }}$ Käännetty väittämästä "Politiikka ei vaikuta tavallisen ihmisen elämään" 


\section{Koulun merkitys yhteiskunnallisten asioiden oppimisessa}

Koulu ja koti koettiin molemmilla luokka-asteilla tärkeimmiksi lähteiksi oppia tietoa yhteiskunnallisten asioiden ymmärtämiseksi. Eri luokkaastetta käyvien nuorten käsitykset niiden tärkeysjärjestyksestä kuitenkin erosivat. 8. luokalla olevat nuoret kokivat kodin tärkeimmäksi lähteeksi oppia tietoa yhteiskunnallisista asioista. Sen sijaan 9.-luokkalaisten keskuudessa koulun merkitys koettiin tärkeimmäksi. Ikäluokkien välisessä vertailussa havaittiin, että koulun merkitys 9. luokalla oli tilastollisesti korkeampi kuin 8. luokalla (taulukko 4). Muiden tietolähteiden kohdalla ei havaittu tilastollisia eroja ikäluokkien välisessä vertailussa. Kun eri tietolähteiden välisiä eroja tarkasteltiin luokka-asteittain, havaittiin, että kaikki erot olivat tilastollisesti merkitseviä (Durbin-Conoverin testi: $\mathrm{p}<0,05)$ lukuun ottamatta ystävä- ja/tai tuttavapiirin sekä itseopiskelun välistä eroa 8 . luokalla.

Taulukko 4. Kahdeksas- ja yhdeksäsluokkalaisten arvio eri tietolähteiden merkityksestä yhteiskunnallisten asioiden oppimisessa

\begin{tabular}{|c|c|c|c|c|c|c|c|c|c|c|c|}
\hline & & \multicolumn{2}{|c|}{$8 \mathrm{lk}$} & \multicolumn{3}{|c|}{$9 \mathrm{lk}}$. & \multicolumn{5}{|c|}{ Mann-Whitneyn U-testi } \\
\hline Kysymys & & $n$ & $k a$ & $k h$ & $n$ & $k a$ & $k h$ & $U$ & $Z$ & $p$ & $r$ \\
\hline \multirow{4}{*}{$\begin{array}{l}\text { Millaisen tietotason } \\
\text { yhteiskunnallisten } \\
\text { asioiden } \\
\text { ymmärtämiseksi } \\
\text { katsot saaneesi...? }\end{array}$} & Koulussa & 67 & 3,06 & 0,83 & 63 & 4,14 & 0,59 & 700 & 2978 & $<0,001$ & 0,67 \\
\hline & Kotona & 67 & 3,30 & 0,85 & 62 & 3,47 & 0,82 & 1869 & $-1,06$ & 0,289 & 0,10 \\
\hline & $\begin{array}{l}\text { Ystävä- ja/tai } \\
\text { tuttavapiirissä }\end{array}$ & 67 & 2,64 & 1,10 & 63 & 2,63 & 0,94 & 2092 & $-0,09$ & 0,928 & 0,01 \\
\hline & $\begin{array}{l}\text { Itseopiskelun } \\
\text { kautta }\end{array}$ & 67 & 2,76 & 1,09 & 63 & 2,86 & 1,01 & 1967 & $-0,699$ & 0,485 & 0,07 \\
\hline
\end{tabular}

Nuorten suhtautumista koulussa saatuun yhteiskunnallisten ja poliittisten asioiden opetukseen mitattiin vielä erillisen väittämäryhmän avulla, jossa vastausasteikko oli neliportainen $(1=$ täysin eri mieltä; 4 = täysin samaa mieltä). Sen tulosten perusteella 9.-luokkalaiset kokivat saaneensa koulussa keskimäärin tarpeeksi tietoa politiikasta ja yhteiskunnallisista asioista $(\mathrm{ka}=3,27 ; \mathrm{kh}=0,64)$, kun taas 8.-luokkalaiset olivat keskimäärin eri mieltä kyseisen väittämän kanssa $(\mathrm{ka}=2,04 ; \mathrm{kh}=0,95)$. Ero luokkaasteiden välillä oli tilastollisesti merkitsevä, $\mathrm{z}=-6,146, \mathrm{p}<0,001 ; \mathrm{r}=0,67$. Vaikka 9.-luokkalaiset $(\mathrm{ka}=1,84 ; \mathrm{kh}=0,91)$ olivat 8.-luokkalaisia $(\mathrm{ka}=1,47 ; \mathrm{kh}=0,77)$ hieman enemmän sitä mieltä, että koulussa käsitellään liikaa politiikkaa ja yhteiskunnallisia asioita, vastaajat olivat kuitenkin molemmilla luokka-asteilla keskimäärin eri mieltä väittämän kanssa $(\mathrm{ka}<2$ asteikolla $1-4)$. Samalla nuoret ajattelivat, että politiikan ja yhteiskunnallisten asioiden käsittelyä pitäisi koulussa pikemminkin lisätä (8. lk $\mathrm{ka}=2,78 ; \mathrm{kh}=0,93 ; 9.1 \mathrm{k} \mathrm{ka}=2,49 ; \mathrm{kh}=0,89)$ kuin että niitä käsiteltäisiin liikaa.

\section{Yhteenveto ja pohdinta}

Tutkimuksen tavoitteena oli selvittää miten edellisen, vuosina 2004-2016 voimassa olleen opetussuunnitelman aikana peruskoulun 8.- ja 9.-luokkalaiset nuoret kiinnittyivät politiikkaan. Yhteenvetona voidaan todeta, että tutkimukseen osallistuneiden 9.-luokkalaisten nuorten poliittinen kiinnostus, tietämys ja itsearvio tietämyksestä olivat tilastollisesti korkeampia kuin 8.-luokkalaisilla nuorilla. Osallistumishalukkuudessa ei havaittu eroja luokka-asteiden välillä, ja politiikkaa koskevien käsitysten osalta eroja ilmeni vain yhden väitteen kohdalla. 
Tutkimuksen tutkimusasetelma on suomalaisessa, lähinnä poikkileikkausaineistoihin perustuvassa poliittisen kiinnittymisen tutkimusperinteessä ainutlaatuinen. Tutkimusaineisto kerättiin yhdessä ja samassa koulussa kahtena ajankohtana: ensimmäisen kerran nuorten ollessa kahdeksannella luokalla ja toisen kerran nuorten ollessa yhdeksännellä luokalla. Vaikka anonyymisti toteutettu aineistonkeruu ei mahdollistanut poliittisessa kiinnittymisessä lukuvuoden aikana tapahtuvien muutosten seuraamista yksilötasolla, mahdollisti tutkimusasetelma vertailut luokkaasteiden välillä. Vastausajankohtien välillä tutkimukseen osallistuneet nuoret opiskelivat lukuvuoden ajan yhteiskuntaoppia ensimmäistä kertaa koulu-urallaan, joten tulokset antavat viitteitä siitä, miten peruskoulun 9. luokalla annettava yhteiskuntaopin opetus onnistui edistämään nuorten poliittista kiinnittymistä tutkimukseen osallistuneessa koulussa ja laaditun mittarin puitteissa.

9.-luokkalaisten nuorten poliittisen tietämyksen havaittiin olevan merkittävästi korkeampaa 8.-luokkalaisiin verrattuna. Tulosta voidaan pitää odotettuna, sillä nuoret opiskelivat mittausajankohtien välissä lukuvuoden yhteiskuntaoppia ja olivat toisen mittauksen ajankohtana vuoden vanhempia kuin ensimmäisellä mittauskerralla. Tulosten perusteella tutkimukseen osallistuvien nuorten poliittisen tietämyksen voidaan kaiken kaikkiaan todeta olleen melko hyvällä tasolla, sillä oikeiden vastausten osuus yksittäisissä kysymyksissä oli yli 50 \% kaikkien muiden paitsi yhden kysymyksen kohdalla. Tutkimustulos on osaltaan linjassa aikaisempien ICCS-tutkimustulosten kanssa, joissa suomalaisnuorten yhteiskunnallisen tietämyksen on havaittu olevan kansainvälisesti verrattuna hyvällä tasolla (Mehtäläinen ym., 2017).

Tutkimukseen osallistuneiden 9.-luokkalaisten nuorten mukaan koulu oli heille tärkein tietolähde yhteiskunnallisten asioiden oppimisessa, kun taas 8.-luokkalaiset pitivät kotia koulua tärkeämpänä tietolähteenä. Koulun merkityksen korostuminen oli merkittävin erotteleva tekijä 9.- ja 8.-luokkalaisten vastausten välillä. Tämä yhdistettynä edellä kuvattuun tulokseen viittaa siihen, että 9. luokalla annettavalla koulun yhteiskuntaopilla olisi ainakin merkitystä nuorten poliittisen tietämyksen kasvattajana. Kovin vahvoja päätelmiä koulun ja yhteiskuntaopin muista mahdollisista vaikutuksista poliittisen kiinnittymisen eri ulottuvuuksiin ei voida kuitenkaan tehdä, koska kyseessä ei ollut koe- ja kontrolliryhmien vertailuun perustuva tutkimusasetelma. Koulutuksen lisäksi havaittujen erojen taustalla saattoivat olla esimerkiksi iän myötä lisääntynyt kiinnostus poliittisia asioita kohtaan tai yksittäinen tapahtuma, joka lisäsi nuorten poliittista kiinnittymistä joko lyhyellä tai pitkällä aikavälillä.

Tutkimusaineisto kerättiin edellisen opetussuunnitelman soveltamisaikana. Vaikka kyseinen vuosina 2004-2016 voimassa ollut opetussuunnitelma painotti perusopetuksen tehtävää nuorten osallistumisen tukijana, tässä tutkimuksessa nuorten osallistumishalukkuudessa ei ilmennyt eroja luokka-asteiden välisessä vertailussa. Lisäksi perinteinen, vaaliosallistumiseen painottuva osallistumishalukkuus oli molemmilla luokkaasteilla korkeampaa kuin ei-perinteinen osallistumishalukkuus, kuten esimerkiksi halukkuus osallistua mielenosoituksiin ja kansalaisaktivismiin. Tähän tutkimukseen vertautuvia asetelmia ei ole toteutettu Suomessa aikaisemmin, mutta tulos heijastelee osaltaan aikaisempia epäilyjä siitä, 
miten yhteiskunnallisen opetuksen tavoitteiden ja todellisuuden välillä näyttäytyisi vallitsevan kuilu (Fornaciari \& Männistö, 2015). Tulos on myös yhtenevä aiemman tutkimuksen kanssa. ICCS-tutkimuksen yhtenä teemana on ollut selvittää, mitä rehtorit ja opettajat pitävät yhteiskunnallisen kasvatuksen tärkeimpinä tavoitteina. Vuoden 2016 tutkimuksessa valmiuksien antaminen tulevaa poliittista osallistumista varten valittiin kaikkien harvimmin tärkeimpien tavoitteiden joukkoon (rehtorit $4 \%$, opettajat $3 \%$ ) (Mehtäläinen ym., 2017, s. 16).

Tutkimustulosten perusteella nuorten käsityksiä politiikasta voidaan pitää pääosin myönteisinä. Politiikkaa myönteisinä kuvaavat väitteet, politiikka on julkista toimintaa ja politiikka on yhteisten asioiden hoitamista, saivat molempina ajankohtina korkeimmat vastauskeskiarvot, ja nuorten mielestä väittämät sopivat hyvin heidän käsityksiinsä politiikasta. 9.-luokkalaisten ikäryhmässä käsitys politiikasta julkisena toimintana oli myös merkitsevästi vahvempaa kuin 8.-luokkalaisilla. Näiden lisäksi useimmat nuoret ajattelivat politiikan vaikuttavan tavallisten ihmisten elämään sekä politiikassa olevan kyse muustakin kuin vain henkilökohtaisen hyödyn tavoittelusta. Havainto on samansuuntainen kuin aikaisempi, täysi-ikäisten suomalaisten politiikkaan liittyviä käsityksiä selvittänyt tutkimustulos, jonka valossa suomalaisten käsitykset politiikasta näyttäytyivät melko myönteisinä (Elo \& Rapeli, 2008, s. 61).

Vaikka molemmat ikäryhmät käsittivät politiikan myönteisenä, poliittinen kiinnostus jäi tuloksissa alhaiseksi. Tulos näyttäytyy ristiriitaisena verrattuna Nuorisobarometri-selvitysten tuloksiin, joissa nuorten poliittista kiinnostusta on mitattu samalla kysymyksellä edellisen kerran vuosina 2012 ja 2018. Niissä haastateltujen nuorimpien ikäluokkien (1519-vuotiaat) poliittinen kiinnostus havaittiin molemmilla mittauskerroilla korkeammaksi kuin tähän tutkimukseen osallistuneiden nuorten kiinnostus (Myllyniemi, 2012; Pekkarinen \& Myllyniemi, 2019). Tätä saattaa kuitenkin osaltaan selittää tämän tutkimuksen otoksen painottuminen 14-15vuotiaiden ikäryhmään, jolloin poliittinen kiinnostus saattaa olla vasta heräämässä. Selitystä tukee tämän tutkimuksen tulos, jonka mukaan 9.luokkalaisten poliittinen kiinnostus oli tilastollisesti korkeampaa kuin 8.luokkalaisten kiinnostus. Tässä tutkimuksessa yhteiskuntaopin opetuksen yhteyttä kiinnostukseen ei kuitenkaan tutkittu suoraan, joten sen mahdolliseen vaikutukseen nuorten kiinnostuksen herättäjänä tulee suhtautua varauksella. Kuten esimerkiksi historian oppiaineen tutkimuksissa on havaittu, opetussuunnitelmissa asetetut tavoitteet eivät välttämättä heijastu käytännön oppitunneilla annettuun opetukseen (Rantala, Puustinen, Khawaja, van den Berg \& Ouakrim-Soivio, 2020). Tätä myöten on myös mahdollista, että nuorten korkeampi kiinnostus 9. luokalla ei selity yhteiskuntaopin opetuksella, vaan se on voinut herätä yhteiskuntaopin opetuksesta huolimatta.

Vaikka tutkimuksen tulokset antavat lisää tietoa nuorten poliittisesta kiinnittymisestä ja yhteiskuntaopin mahdollisesta osuudesta osana tätä prosessia, liittyy tutkimusasetelmaan ja tulosten yleistettävyyteen rajoituksia. Tutkimukseen osallistui oppilaita vain yhdestä koulusta, ja osallistujien lukumäärä oli melko pieni $(8.1 \mathrm{k}: \mathrm{n}=67 ; 9.1 \mathrm{k}: \mathrm{n}=63)$, joten tutkimustuloksia ei voida yleistää koskemaan laajempaa nuorten joukkoa. Tutkimuksen tuloksia voidaan kuitenkin hyödyntää muodostettaessa 
hypoteeseja ja tutkimusasetelmia myöhemmille jatkotutkimuksille. Tässä tutkimuksessa ei havaittu eroja eri ikäluokkiin kuuluvien nuorten yhteiskunnallisessa osallistumishalukkuudessa. Esitämmekin, että erityisesti sen osalta olisi tärkeää tehdä jatkotutkimusta laajemmilla pitkittäisasetelmilla, jotka mahdollistaisivat osallistumishalukkuuden kehittymisen seurannan yksilötasolla.

Myös tässä tutkimuksessa hyödynnetty kyselymittari sisältää rajoitteita, jotka on syytä tiedostaa tulosten luotettavuutta arvioitaessa. Tutkimuksen päämittari on alun perin kehitetty mittaamaan täysi-ikäisten poliittista tietämystä ja poliittiseen kiinnittymiseen liittyviä taustamuuttujia. Tämä näkyy esimerkiksi siinä, että sen poliittista osallistumishalukkuutta kuvaavassa osiossa painottuu vaaleihin ja puolueisiin liittyvä osallistuminen eikä siinä huomioida erityisesti peruskouluikäisille ajankohtaisempia osallistumistapoja. Lisäksi mittarin politiikkakäsityksiä mittaavat väittämät heijastelevat melko kapeaa käsitystä politiikasta eivätkä mahdollista nuorten itse muotoilemien politiikkakäsitysten tarkastelua. Mittarin eri osa-alueiden kysymykset ja väittämät sisältävät myös paljon monitulkintaisia käsitteitä, mikä tarkoittaa sitä, että vastaajat ovat voineet tulkita kysymyksiä eri tavoin. Tämä taas on saattanut johtaa vastausten yhteismitallisuuden vääristymiseen. Tulevissa poliittista kiinnittymistä mittaavissa tutkimuksissa olisikin perusteltua harkita keskeisten käsitteiden määrittelemistä kysymysten yhteydessä.

Vaikka tähänkin tutkimukseen valitulla määrällisellä lähestymistavalla on roolinsa poliittisessa kiinnittymisessä havaittujen erojen havaitsemissa, olisi jatkossa hyödyllistä keskittyä myös laadullisen ymmärryksen syventämiseen, ja tutkia, miten nuoret ylipäätään ymmärtävät ja käsittävät yhteiskunnan ja politiikan käsitteet. Laadulliseen tutkimukseen tukeutuen olisi myös mahdollista modernisoida kyselymittareita ottamaan huomioon ajankohtaisia ja uusia osallistumismuotoja, kuten sosiaalisen median mahdollistamia uusia tapoja viestiä ja vaikuttaa. Mittareissa tulisi poliittisen tietämyksen lisäksi huomioida myös poliittisen ja yhteiskunnallisen tiedon soveltaminen erilaisissa tilanteissa, jota uusi perusopetuksen opetussuunnitelmakin painottaa (Opetushallitus, 2014, s. 260). Lisäksi tutkimusasetelmissa tulisi huomioida koulun lisäksi perheen, ystäväpiirin, median ja muiden koulun ulkopuolisten sosialisaatioympäristöjen vaikutus poliittisen kiinnittymisen eri ulottuvuuksiin.

Tämän tutkimuksen aineistonkeruun jälkeen on otettu käyttöön uusi perusopetuksen opetussuunnitelma, jossa yhteiskuntaopin opetus on ulotettu alkamaan vuosiluokilla 4-6. Vuonna 2016 voimaan astuneen uudistuksen yhtenä tavoitteena on ollut lisätä ja aikaistaa opetusta yhteiskunnallisen vaikuttamisen periaatteista (Opetus- ja kulttuuriministeriö, 2012, s. 39-40). Opetuksen kohdistuessa aikaisempaa nuorempaan ikäluokkaan olisi tarpeellista tutkia ja määritellä tarkemmin minkälaisiin yhteiskunnallisen osallistumisen muotoihin opetuksen tavoitteiden tulisi painottua sekä millaiset opetusmenetelmät palvelisivat parhaiten tavoitteiden saavuttamista. Samalla olisi ajankohtaista kehittää aikaisempaa nuoremmille ikäluokille opetusmenetelmiä, joita voitaisiin hyödyntää myös peruskoulun ylemmillä luokilla. 


\section{Ainedidaktiikka 5(1) (2021)}

Yhteiskunnallisen kasvatuksen vahvuutena on Suomessa ollut tiedollisten valmiuksien kehittäminen, mitä käsitystä tämänkin tutkimuksen tulokset osaltaan tukevat. Jatkossa tulisi kiinnittää huomiota myös siihen, miten tiedollisten sisältöjen omaksumisen lisäksi koulussa voitaisiin tukea ja edistää nuorten yhteiskunnallista osallistumishalukkuutta ja -valmiuksia. Tämä edellisen opetussuunnitelman aikana kerätty aineisto ja siihen liittyvät tulokset toimivat hyvänä pohjana ja vertailukohtana uuden opetussuunnitelman aikana toteutettaville vastaaville tutkimuksille.

\section{Lähteet}

Andolina, M. W. \& Conklin, H. G. (2018). Speaking with confidence and listening with empathy: the impact of Project Soapbox on high school students. Theory \& Research in Social Education, 46(3), 374-409. https://doi.org/10.1080/00933104.2018.1435324

Barrett, M. \& Brunton-Smith, I. (2014). Political and civic engagement and participation: Towards an integrative perspective. Journal of Civil Society 10(1), 5-28. https://doi.org/10.1080/17448689.2013.871911

Barrett, M. \& Pachi, D. (2019). Youth civic and political engagement. Abingdon/New York: Routledge.

Bengtsson, Å. \& Grönlund, K. (2005). Muu poliittinen osallistuminen. Teoksessa H. Paloheimo (toim.), Vaalit ja demokratia Suomessa (s. 147-168). Helsinki: WSOY.

Brady, H. (1999). Political Participation. Teoksessa J. P. Robinson, P.R. Shaver \& L. S. Wrightsman (toim.), Measures of political attitudes (s. 737-801). San Diego: Academic Press.

Cammaerts, B., Bruter, M., Banaji, S., Harrison, S. \& Anstead, N. (2014). The myth of youth apathy: Young Europeans' critical attitudes toward democratic life. American Behavioral Scientist, 58(5), 645-664. https://doi.org/10.1177/0002764213515992

Campbell, D. E. (2008). Voice in the classroom: how an open classroom climate fosters political engagement among adolescents. Political Behavior, 30(4), 437-454. https://doi.org/10.1007/s11109-008-9063-z

Crouch, D. (2018). The Swedish 15-year-old who's cutting class to fight the climate crisis. The Guardian (19.2018).

https://www.theguardian.com/science/2018/sep/01/swedish-15-year-old-cuttingclass-to-fight-the-climate-crisis

Delli Carpini, M. X. \& Keeter, S. (1996). What Americans know about politics and why it matters. New Haven: Yale University Press.

Dassonneville, R., Quintelier, E., Hooghe, M. \& Claes, E. (2012). The relation between civic education and political attitudes and behavior: a two-year panel study among Belgian late adolescents. Applied Developmental Science, 16(3), 140-150. https://doi.org/10.1080/10888691.2012.695265

van Deth, J. W. (1990). Interest in politics. Teoksessa M. K. Jennings \& J. W. van Deth (toim.), Continuities in political action: A longitudinal study of political orientations in three western democracies (s. 275-312). Berlin/Boston: De Gruyter. https://doi.org/10.1515/9783110882193.275

Easton, D. \& Dennis, J. (1969). Children in the political system: Origins of political legitimacy. New York: McGraw-Hill.

Elo, K. (2009). Kiinnostuksesta se kaikki lähtee...: Havaintoja äänestysikää lähestyvien nuorten politiikkatietämyksestä. Kasvatus, 40(1), 36-48. http://urn.fi/URN:NBN:fi:ELE-1484206

Elo, K. \& Rapeli, L. (2008). Suomalaisten politiikkatietämys. Oikeusministeriön julkaisuja 2008: 6. Helsinki: Oikeusministeriö. http://urn.fi/URN:ISBN:978-952-466-800-2

Eränpalo, T. (2012). Onko kuva suomalaisnuorten yhteiskunnallisesta passiivisuudesta harhaa? Kasvatus \& Aika, 6(1), 23-38.

https://journal.fi/kasvatusjaaika/article/view/68310 


\section{Ainedidaktiikka 5(1) (2021)}

Fornaciari, A. \& Männistö, P. (2015). Yhteiskunta-ja demokratiakasvatuksen sudenkuoppa. Opettajien avulla kohti kriittisempää kansalaisuutta. Kasvatus \& Aika, 9(4). 72-86. https://journal.fi/kasvatusjaaika/article/view/68556/29828

Galston, W. A. (2001). Political knowledge, political engagement, and civic education. Annual Review of Political Science, 4(1), 217-234. https://doi.org/10.1146/annurev.polisci.4.1.217

Harrinvirta, M. (2019). Nuoret kansanvallan suunnannäyttäjinä. Onko Suomessa näkyvissä demokratiasta vieraantumista? Teoksessa E. Pekkarinen \& S. Myllyniemi (toim.), Vaikutusvaltaa Euroopan laidalla. Nuorisobarometri 2018 (s. 115-130). Nuorisotutkimusseuran verkkojulkaisuja nro 140 \& Valtion nuorisoneuvoston julkaisuja nro 60. Helsinki: Valtion nuorisoneuvosto, Nuorisotutkimusseura, Nuorisotutkimusverkosto, Opetus- ja kulttuuriministeriö. https://tietoanuorista.fi/wp-content/uploads/2019/03/NB 2018 web.pdf

Jensen, M. J., Jorba, L. \& Anduiza, E. (2012). Introduction. Teoksessa E. Anduiza, E. A. Perea, M. J. Jensen \& L. Jorba (toim.), Digital media and political engagement worldwide: A comparative study (s. 1-15). Cambridge: Cambridge University Press. https://doi.org/10.1017/CBO9781139108881.001

Kestilä-Kekkonen, E. (2015). Suomalaisten poliittinen kiinnittyminen. Teoksessa S. Borg, E. Kestilä-Kekkonen \& J. Westinen (toim.), Demokratiaindikaattorit 2015 (s. 52-63). Oikeusministeriön selvityksiä ja ohjeita 2015: 56. Helsinki: Oikeusministeriö. http://urn.fi/URN:ISBN:978-952-259-483-9

Koskimaa, V. \& Rapeli, L. (2015). Political socialization and political interest: The role of school reassessed. Journal of Political Science Education, 11(2), 141-156. https://doi.org/10.1080/15512169.2015.1016033

Leftwich, A. (2004). Thinking Politically: On the politics of Politics. Teoksessa A. Leftwich (toim.), What is Politics? (s. 1-22). Cambridge: Polity Press.

Löfström, J., Virta, A. \& Salo, U. M. (2017). Valppaaksi kansalaiseksi: Yhteiskuntatiedollisen opetuksen taito ja teoria. Helsinki: Historiallis-yhteiskuntatiedollisen kasvatuksen tutkimus- ja kehittämiskeskuksen tutkimuksia. http://hdl.handle.net/10138/233471

Marsh, A. \& Kaase, M. (1979). Measuring Political Action. Teoksessa S. H. Barnes, \& M. Kaase (toim.), Political Action: Mass Participation in Five Western Democracies (s. 58-97). Beverly Hills: Sage.

McCartney, A. R. M. (2013). Teaching civic engagement: Debates, definitions, benefits, and challenges. Teoksessa A. R. M. McCartney, E. A. Bennion \& D. W. Simpson (toim.), Teaching civic engagement: From student to active citizen (s. 9-20). Washington, DC: American Political Science Association. https://web.apsanet.org/teachingcivicengagement/wp-content/uploads/sites/9/2016/10/TeachingCivicEngagementBW.pdf

McIntosh, H. \& Youniss, J. (2010). Toward a political theory of political socialization of youth. Teoksessa L. R. Sherrod, J. Torney-Purta \& C. A. Flanagan (toim.), Handbook of research on civic engagement in youth (s. 23-41). Hoboken, NJ: Wiley. https://doi.org/10.1002/9780470767603.ch1

Mehtäläinen, J., Niilo-Rämä, M. \& Nissinen, V. (2017). Nuorten yhteiskunnalliset tiedot, osallistuminen ja asenteet: kansainvälisen ICCS 2016-tutkimuksen päätulokset. Jyväskylä: Koulutuksen tutkimuslaitos. http://urn.fi/URN:ISBN:978-951-39-7230-1

Meighan, R. \& Harber, C. (2007). A sociology of educating. Lontoo: Bloomsbury Publishing.

Milner, H. (2002). Civic literacy: How informed citizens make democracy work. Hanover, NH: University Press of New England.

Myllyniemi, S. (toim.) (2012). Monipolvinen hyvinvointi. Nuorisobarometri 2012. Nuorisotutkimusverkosto/Nuorisotutkimusseura, julkaisuja, 127, verkkojulkaisuja 53. Hybridit. Nuorisoasiain neuvottelukunta, julkaisuja 46. Helsinki: Opetusja kulttuuriministeriö.

https://tietoanuorista.fi/wp-content/uploads/2013/05/Nuorisobarometri 2012 Verkkojulkaisu.pdf

Neundorf, A., Niemi, R. G. \& Smets, K. (2016). The Compensation Effect of Civic Education on Political Engagement: How Civics Classes Make Up for Missing Parental Socialization. Political Behavior, 38(4), 921-949.

https://doi.org/10.1007/s11109-016-9341-0 


\section{Ainedidaktiikka 5(1) (2021)}

Niemi, R. G. \& Junn, J. (1998). Civic education: What makes students learn. New Haven, CT: Yale University Press.

Opetushallitus (2004). Perusopetuksen opetussuunnitelman perusteet 2004. Helsinki: Opetushallitus.

Opetushallitus (2014). Perusopetuksen opetussuunnitelman perusteet 2014. Helsinki: Opetushallitus.

Opetus- ja kulttuuriministeriö (2012). Tulevaisuuden perusopetus - valtakunnalliset tavoitteet ja tuntijako. Opetus- ja kulttuuriministeriön työryhmämuistioita ja selvityksiä 2012: 6. Helsinki: Opetus- ja kulttuuriministeriö.

Pekkarinen, E. \& Myllyniemi S. (2019). Vaikutusvaltaa Euroopan laidalla. Nuorisobarometri 2018. Nuorisotutkimusseuran verkkojulkaisuja nro 140 \& Valtion nuorisoneuvoston julkaisuja nro 60. Helsinki: Valtion nuorisoneuvosto, Nuorisotutkimusseura, Nuorisotutkimusverkosto, Helsinki: Opetus- ja kulttuuriministeriö. https://tietoanuorista.fi/wp-content/uploads/2019/03/NB 2018_web.pdf

Putnam, R. D. (2000). Bowling alone: The collapse and revival of American community. New York: Simon \& Schuster.

Rantala, J., Puustinen, M., Khawaja, A., van den Berg, M. \& Ouakrim-Soivio, N. (2020). Näinkö historiaa opitaan? Helsinki: Gaudeamus.

Rapeli, L. (2010). Tietääkö kansa? Kansalaisten politiikkatietämys teoreettisessa ja empiirisessä tarkastelussa. (Väitöskirja). Turun yliopisto. http://urn.fi/URN:ISBN:978-951-29-4219-0

Rapeli, L. (2013). The Conception of Citizen Knowledge in Democratic Theory. Basingstoke: Palgrave MacMillan. https://doi.org/10.1057/9781137322869

Suoninen, A., Kupari, P. \& Törmäkangas, K. (2010). Nuorten yhteiskunnalliset tiedot, osallistuminen ja asenteet: kansainvälisen ICCS 2009-tutkimuksen ensituloksia. Jyväskylä: Koulutuksen tutkimuslaitos.

http://urn.fi/URN:ISBN:978-951-39-4107-9

Teorell, J., Torcal, M. \& Montero, J. R. (2007). Political participation: mapping the terrain. Teoksessa J. W. van Deth, J. R. Montero \& A. Westholm (toim.), Citizenship and involvement in European democracies: A comparative analysis (s. 334-357). Abingdon/New York: Routledge.

Tomperi, T. (2011). Poliittinen sosialisaatio perheissä. Tutkimuksen perinteestä nykynäkymiin. Nuorisotutkimus, 29(3), 3-28. https://urn.fi/URN:NBN:fi:ELE-1755249

Torney-Purta, J. (2002). The school's role in developing civic engagement: A study of adolescents in twenty-eight countries. Applied Developmental Science, 6(4), 203212. https://doi.org/10.1207/S1532480XADS0604 7

Wass, H. (2007). The effects of age, generation and period on turnout in Finland 19752003. Electoral Studies, 26(3), 648-659. https://doi.org/10.1016/j.electstud.2007.06.002 